\title{
Role of inulin as prebiotics on inflammatory bowel disease
}

\author{
Wasim Akram*, Navneet Garud, Ramakant Joshi \\ School of Studies in Pharmaceutical Sciences, Jiwaji University, Gwalior, India.
}

\begin{abstract}
Summary The present review is focused on the prebiotic impact of inulin on the management of the gastrointestinal disorder. Prebiotics can be described as "non-digestible food ingredient stimulating the growth of a certain number of bacteria in the colon, which can improve the host health". In 2004 this definition was modernized to include other areas that may benefit from selective targeting of particular microorganisms: "selectively fermented ingredients that alter the configuration and activity in the gastrointestinal microbiota that confer positive effect". The positive impact of prebiotics in experimental colitis and human inflammatory bowel disease (IBD) has already been established. Prebiotics shows a positive effect in the prevention of IBD by modulating the trophic functions of the flora. Inulin enhances the growth of indigenous lactobacilli and/or bifidobacteria by inducing colonic production of short chain fatty acids (SCFA's) and these properties are related to decreased mucosal lesion scores and diminished mucosal inflammation. Inulin shows a positive approach to retain microbial populations and to support epithelial barrier function by their prebiotic effect which helps in the host defense against invasion and pathogens translocation (endogenous and/or exogenous) and in the inhibition of gastrointestinal diseases and this impact should be verified in further clinical studies. In the present review, we discussed the positive effect of prebiotics in rat IBD models and in human subjects along with their potential protective mechanisms. Preclinical and clinical data revealed that the gut mucosal barrier would be improved by the use of prebiotics in IBD.
\end{abstract}

Keywords: Inulin, prebiotics, microflora, inflammatory bowel disease

\section{Introduction}

Inflammatory bowel disease (IBD) refers to a variety of multifactorial dysfunctions that arise in the digestive system (1) and are recognised by intense inflammation of the gastrointestinal tract (2) due to abnormal immune responses (3). This gastrointestinal inflammation includes Crohn's disease (CD) and ulcerative colitis (UC). Recent findings revealed that IBD complication is originated from genetic, ecological and unusual immunological factors (4). The eating regimen, lifestyle and other vulnerable endogenous elements such as gut microflora are involved in the development of disease (2). The research studies proposed that the human bowel microbiota generates antigenic factors which trigger the persistent inflammation of the intestinal mucosa

*Address correspondence to:

Wasim Akram, School of Studies in Pharmaceutical Sciences, Jiwaji University, Gwalior, M.P-474011, India.

E-mail: wasimjiwaji@gmail.com as observed in CD and UC (5-7). This information has directed to an emerging therapeutic tactic that pins the microbiota of patients having IBD using agents like prebiotics (inulin) which work primarily by stimulating the growth or increasing the numbers of certain bacteria and thus quantitatively transforming the microflora (8). When prebiotics reaches to the colon are fermented by anaerobic bacteria, yielding shortchain fatty acids (SCFA). As a result, intraluminal $\mathrm{pH}$ decline (9). An increase of Bifidobacteria, Lactobacilli and non-pathogenic $E$. coli in colon are accountable for antimicrobial activity, immunomodulation, and induction of an immune response, and improvement of barrier activity that confers health benefits to the host (10-12).

The management of IBD consists of employing antibiotics, immunomodulators, and biological therapies (Table 1), even though they show toxicity have less therapeutic benefits for the treatment of UC (13). In addition, the present treatments are frequently directed against the highly intense adaptive immune response of the host but fail to precise probable environmental 
Table 1. Outline of the approaches used for IBD (18)

\begin{tabular}{|c|c|c|}
\hline Therapeutic Agent & Disease Conditions & Method of Delivery \\
\hline 5-Aminosalicylate & Mild to moderate & Oral, topical \\
\hline Corticosteroids & Mild to critical & Oral, topical, Intravenous \\
\hline $\begin{array}{l}\text { Immunomodulators: } \\
\text { - Azathiopurines } \\
\text { - } 6 \text { Mercaptopurines } \\
\text { - Cyclosporin A } \\
\text { - TAcrolimus } \\
\text { - Methotrexateen }\end{array}$ & $\begin{array}{l}\text { Moderate to critical } \\
\text { steroid-dependent } \\
\text { and steroid-refractory } \\
\text { disease fistulising }\end{array}$ & Oral, topical, injection \\
\hline $\begin{array}{l}\text { Antibiotics: } \\
\text { - Metronidazole } \\
\text { - Ciprofloxacin }\end{array}$ & Active & Oral, intravenous \\
\hline $\begin{array}{l}\text { Biological Therapies: } \\
\text { - Adalimunab } \\
\text { - Certolizumabpegol } \\
\text { - Inflixmab }\end{array}$ & $\begin{array}{l}\text { Modern tocritical } \\
\text { Fistulising }\end{array}$ & $\begin{array}{l}\text { Intravenous, injection, } \\
\text { infusion }\end{array}$ \\
\hline $\begin{array}{l}\text { Probiotics \& Prebiotics: } \\
\text { - EscherichiacoliNissle1917 } \\
\text { - Fructooligosaccharide } \\
\text { - Glucomannanhydrolysate }\end{array}$ & Remission maintenance & Ingestion \\
\hline
\end{tabular}

Table 2. Research studies that recommend intestinal microflora involvement in pathological process of IBD

Subjects retained under precise germ-free conditions do not experienceinflammation unless microorganismis introduced $(19,20)$

In patients with $\mathrm{CD}$, the number of adherent mucosal bacteria is increased (21)

Inflammation arises in intestinal regionswith the maximum number of bacteria (22)

Luminal and mucosa-linked microflora of IBD subjects varies from healthy subjects $(23,25)$

Alteration of the fecal stream triggers clinical progress in Crohn's patients (25)

triggers like intestinal microbiota that provokes and perpetuate these ailments (Table 2). In addition, a microbial imbalance exists between disease-causing and defensive intestinal microflora in subjects with IBD (Table 3).

The above drawback led to newer approaches for the treatment of IBD-like prebiotics, probiotics or a combination of the two (synbiotics). Using prebiotics as a therapeutic agent or adjuvant to conventional therapy could prove an efficacious tool for the treatment of a series of physiological disorders. The data obtained from limited preclinical and clinical findings have studied the impact of prebiotics on UC and CD (1416). The various research findings show that unrefined fibre-rich carbohydrates show a prominent effect on the management of CD (17).

\section{Inulin a versatile biopolymer}

\subsection{Origin and identity}

Rose, a German scientist discovered inulin in 1804 from the roots of Inulahelenium, a genus of perennial herbs of the group Compositae, inhabitants of the temperate regions of Europe, Asia, and Africa (27). Inulin was also referred by other names such ashelenin, alantin, meniantin, dahlin, sinantemin, and sinisterin.

Inulin comes under a general class of fructose-
Table 3. Microbial imbalance among disease-causing and defensive intestinal bacteria in subjects with IBD (26)

\begin{tabular}{ll}
\hline Defensive Bacteria & Disease-causing Bacteria \\
\hline Bifidobacterium & Selected Bacteroides \\
Lactobacillus & Enterococcus faecalis \\
Streptococcus salivarius & Enterobacter cloacae \\
Saccharomyces boulardii & Fusobacterium \\
Clostridium butyricum & Intestinal Helicobacter \\
E. coli Nissle 1917 & Entero-invasive E.coli \\
Ruminococci & Eubacterium \\
& Peptostreptococcus \\
\hline
\end{tabular}

containing polymers known as fructans. Fructans assist as storage polymers in numerous members of the Compositae family such as Cichoriumintybus (chicory), Inulahelenium (elecampane), Taraxacumofficinalis (dandelion) and Helianthus tuberosus (Jerusalem artichoke). Inulin is extracted from chicory is a natural polydisperse carbohydrate (28). Inulin is a fructan which mainly comprises of 1, 2-[3-1inked d-fructofuranose units bound by an (od-132) type linkage to a terminal glucose moiety. By assessment, inulin primarily made up of linear fructose units tied by a $\beta-(2-6)$ glycosidic bond (Figure 1) (31).

\subsection{Versatile applications}

Inulin a versatile biopolymer has a variety of applications in the Pharmaceutical arena, Food arena 


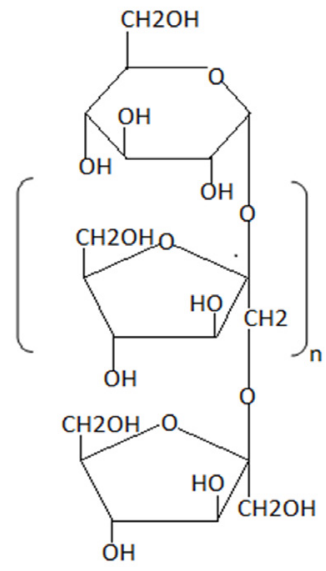

Figure 1. The molecular structure of inulin.

Table 4. Key Applications of Inulin in a distinct area

\begin{tabular}{|c|c|c|}
\hline Category & Application/Uses & Ref. \\
\hline Pharmaceutical & Stabilisation & \\
\hline \multirow[t]{16}{*}{ Applications } & - Anhydrobiosis & $(29)$ \\
\hline & - Protein stabilization & $(30)$ \\
\hline & Drug Delivery & \\
\hline & - Solution behaviour alteration & \\
\hline & - Solution rate enhancement & $(31)$ \\
\hline & - Local drug delivery & \\
\hline & - Colon targeting & $(32)$ \\
\hline & - Pulmonary delivery & (33) \\
\hline & Physiological and disease & \\
\hline & modifying effect & \\
\hline & - Systemic & \\
\hline & - Vaccine Adjuvant & (34) \\
\hline & - Diagnosis of kidney & (35) \\
\hline & $\begin{array}{c}\text { functioning } \\
\text { - Gastrointestinal tract }\end{array}$ & \\
\hline & - Constipation & $(36)$ \\
\hline & - IBD \& colon cancer & $(37)$ \\
\hline Food & Fibre enrichment & $(38)$ \\
\hline \multirow[t]{3}{*}{ Applications } & As a prebiotic & (39) \\
\hline & As a fat replacer & $(40)$ \\
\hline & As a sugar replacer & $(41)$ \\
\hline \multirow{7}{*}{$\begin{array}{l}\text { Nutritional and } \\
\text { health benefits }\end{array}$} & Function as dietary fiber & $(42)$ \\
\hline & Effect on lipid metabolism & (43) \\
\hline & Effect on constipation and stool frequency & (44) \\
\hline & Bifidogenic effect & $(45)$ \\
\hline & Reduction in risk of gastrointestinal diseases & $(46)$ \\
\hline & Stimulation of the immune system & $(47)$ \\
\hline & Intestinal acceptability & $(48)$ \\
\hline
\end{tabular}

and also have nutritional and health benefits. In the present review, diverse application of inulin has been summarized in Table 4, but the study mainly focused on the prebiotic impact of inulin on IBD.

Prebiotics can be described as "non-digestible food ingredient stimulating the growth of a certain number of bacteria in the colon, which can improve the host health" (53). In 2004 the definition of prebiotic was modernized to involve other areas that may take advantages from selective targeting of specific microflora: "selectively fermented ingredients that alter the configuration and activity in the gastrointestinal microbiota that confer positive effect" (49). Indigenous Bifidobacteria and Lactobacilli microbial genera are

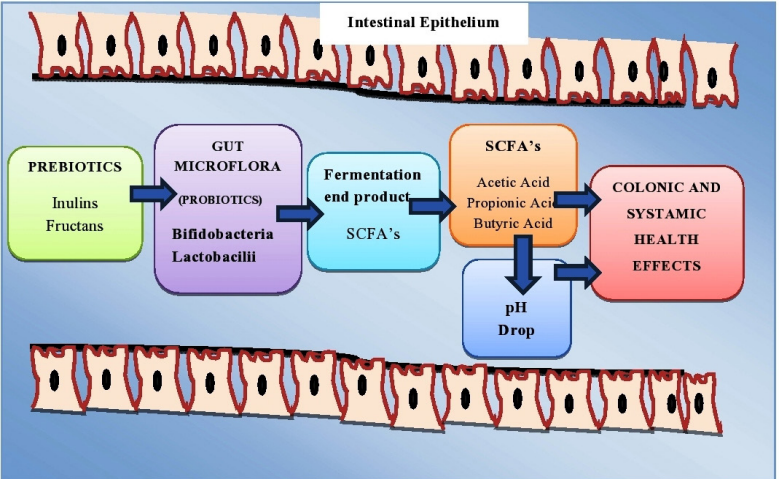

Figure 2. Mechanism of prebiotic action.

directed for selective stimulation (50).

Prebiotics aid as a source of food for probiotics to raise, proliferate and increase in numbers on the bowel microflora. Through the fermentation by the anaerobic microflora, short-chain fatty acids (acetate, propionate, and butyrate) are formed as the end products which are responsible for colonic $\mathrm{pH}$ drop and prevent the development of pathogenic microflora (Figure 2). These positive effects are mainly based on the nature and amounts of the prebiotic used in an eating regimen, as well as the density of Bifidobacteria on the gut of the host $(51,52)$. Moreover, these prebiotics shows a positive effect on the deterrence of IBD by modulating the trophic functions of the flora and providing other health benefits.

\section{Involvement of intestinal flora in IBD}

Improvement in the last few years has been done to acquire a better consideration but still, the precise pathological process of IBD is quite unknown. Current finding in the etiology of IBD proposed that the combination of genetical, immunological and ecological parameters is responsible for the occurrence of this disorder. The role of intestinal microflora in the pathogenesis of IBD is well known (53), primarily in Crohn's condition. This persistent bowel inflammation usually appears at terminal ileum and colon, the zone with the maximum intestinal microflora concentration. Antibiotics and faecal diversion are the remedies for $\mathrm{CD}$ although regenerating endurance of the bypassed distal colon or intestinal matters infusion into the omitted ileum may cause a return of disease (5). In numerous rat models of chronic intestinal inflammation, the consequence of bowel microflora in the commencement and perpetuation of chronic bowel infection is most credibly validated (54).

After 56 days of birth transgenic rats HLA-B27 develop colitis in the presence of usual bowel microflora (55), while in non-transgenic rats, antibioticcured transgenic rats, and microbe-free transgenic rats there is no evidence of the occurrence of disease $(56,57)$. Aggravation of colitis can be associated with an 


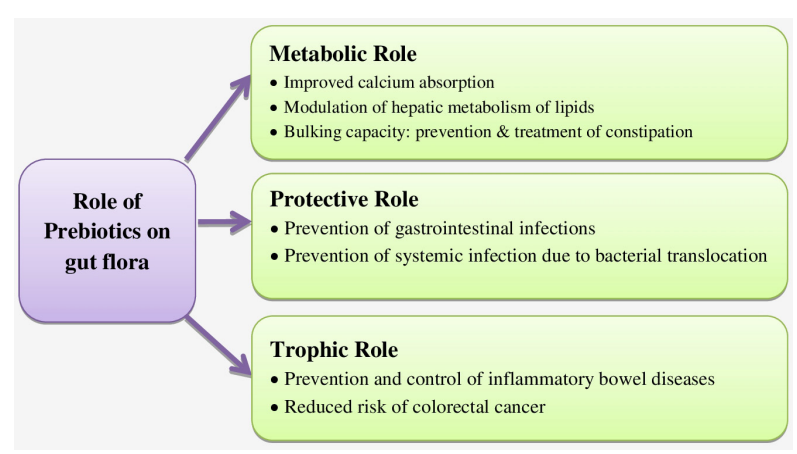

Figure 3. Role of prebiotics on gut flora.

amplified concentration of luminal Bacteroides species (58). In the distal intestine Bacteroides spp. is the most dominant. After surgical resection postoperative relapse of CD is related to amplify Bacteroides species (59). Most importantly, after monoassociation for 4 weeks $B$. vulgate causes intestinal inflammation in transgenic rats, while monoassociation with $E$. coli does not show any disease condition (60). As a result, all bacteria are not equivalent in their capability to cause intestinal inflammation.

\section{Prebiotics in inflammatory bowel diseases}

Numerous studies have verified the role of prebiotics on gut flora (Figure 3) and also verified that the metabolic functionality of the intestinal flora can be increased by utilization of prebiotics. For example, there is abundant proof revealing in human research that absorption of calcium improves by inulin-type fructans. Similarly, animal experiments have confirmed that the hepatic metabolism of lipids enhances by fermentation of oligofructose and may elude dysfunctions linked with non-alcoholic steatohepatitis and metabolic syndrome. The bulking capacity of inulin-type fructans shows benefits for metabolic bowel functions and can also help in the inhibition and treatment of constipation. The improvement in the gut barrier has also been shown by prebiotics treatment. Prebiotics are considered to be safe, non-toxic and shows a positive effect in the inhibition and management of gastrointestinal disease on the basis of large number studies on clinical trials (61-70).

\subsection{Inulin effect in animal models}

The prebiotics impacts on bowel inflammation already been studied in various animal models. Mice lacking IL-10 gene impulsively develop colitis. There is a low level of Lactobacillus species in the colon in the neonatal period of these mice and also have an elevation in adherent and translocated bacteria (71). The count of lactobacilli in faeces was shown to normalize by rectal delivery of Lactobacillus reuteri and this prevents the expansion of colitis. In the same animal model, mucosal

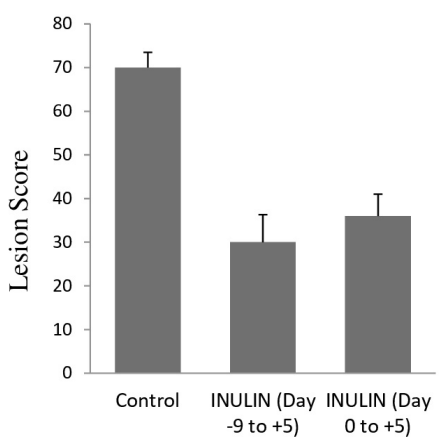

Figure 4. Histological scores in rats with colitis provoked by dextran sodium sulfate (DSS). Insulin-treated rats $(400$ $\mathrm{mg} / \mathrm{d})$ indicated lower lesion scores than controls $(* p<0.05$ $v s$. control). Inulin treatment in progress either 9 days before exposure to DSS (day -9 to +5 ) or at the same time as the exposure to DSS (day 0 to +5 ) and was continued for the 5 days on DSS (75)

lesion scores and inflammatory activity is reduced by oral administration of either Lactobacillus salivarius or Bifidobacterium infantis (72). A genetically engineered bacterium in IL-10 knockout mouse model produces the anti-inflammatory cytokine IL-10 that prevent the onset of colitis (73). Though, the colitis provokes with the help of trinitrobenzene sulphonic acid in the rat did not diminish probiotic therapy with Lactobacillus plantarum (74). The experimental findings with probiotics have revealed that the impulsively grow inflammatory mucosal lesions in mice knockout of the $I L-10$ gene is prevented by increasing the amounts of lactobacilli or bifidobacteria in the colonic lumen.

The inulin prebiotic impact was studied in dextran sodium sulfate (DSS) evoked distal colitis in a rat model, which histologically bears a resemblance to human UC (75). By daily administration of inulin through oral route the indigenous lactobacilli counts are amplified in the lumen of the caecum and also decrease the $\mathrm{pH}$ of colonic. Inulin nourishing prolonged the saccharolytic section (only right colon) that brings about an acidic atmosphere in the left colon. In the rats with DSS evoked colitis themucosal inflammation and histological damage scores are reduced by orally administered inulin (Figure 4) (75). Moreover, the rats fed with inulin exhibited a lower degree of mucosal damage and reduced harshness of crypt damage, as compared to controls. Management with orally administered inulin had been equally showing positive effect whether treatment offered ahead of or during exposure of DSS.

For the management of chronic colitis making use of prebiotics are promising and also have been executed frequently in animal models (Table 5). Nourishing inulin and oligofructose combination at $5 \mathrm{~g} / \mathrm{kg}$ body weight diminishes intestinal inflammation in transgenic rats (76). The model HLA-B27 transgenic rat is used to judge prebiotic action working mechanisms in chronic colitis in this research study. This positive outcome was seen with a rise of intestinal bifidobacteria and 
Table 5. Prebiotic treatment on a colitis induced animal model

\begin{tabular}{llll}
\hline Ref. & \multicolumn{1}{c}{ Treatment } & Animal Model & Result \\
\hline Videla et al. $(76)$ & Dietary inulin & DSS-induced colitis in rats & Improvement distal colitis \\
Holma et al. $(82)$ & Galacto-oligosaccharides & TNBS-induced colitis in rats & No reduction of colitis \\
Moreau et al. $(81)$ & Oligofructose & DSS-induced colitis in rats & No reduction of colitis \\
Hoentjen et al. $(77)$ & Oligofructose-enriched inulin & HLA-B27 transgenic rat & Reduction of colitis \\
Daddaoua et al. $(80)$ & Goat milk oligosaccharides & Hapten-induced colitis & Colitis reduction \\
Lara-Villoslada et al. $(79)$ & Goat milk oligosaccharides & DSS-induced colitis in rats & Colitis reduction \\
\hline
\end{tabular}

Table 6. Clinical trials of prebiotic treatment in IBD

\begin{tabular}{|c|c|c|c|c|c|c|}
\hline Ref. & Study & $n$ & Clinical Condition & Treatment & Duration of Treatment & Result \\
\hline Welters et al. (83) & $\begin{array}{c}\text { Double-blind } \\
\text { placebo-controlled trial }\end{array}$ & 20 & Chronic pouchitis & $\begin{array}{l}\text { Dietary inulin } \\
24 \mathrm{~g} / \mathrm{d}\end{array}$ & 6 week & $\begin{array}{l}\text { Effective in the treatment of } \\
\text { chronic pouchitis }\end{array}$ \\
\hline Lindsay et al. (85) & Open-labeled trial & 10 & Active CD & Synergy $15 \mathrm{~g} / \mathrm{d}$ & 3 week & Reduction of disease activity \\
\hline
\end{tabular}

lactobacilli. Similarly, colitis-prone rats nourish by prebiotic combination (inulin and oligofructose) decreases mucosal proinflammatory cytokines and also immunoregulatory altering growth factor- $\beta$ is amplified. The research studies reported a positive effect in transgenic rats with inulin plus probiotics (77). Diminished clinical indications and amplified MUC3 manifestation were perceived compared with control rats in dextran sodium sulphate evoked colitis rats which were nourished with goat's milk oligosaccharides (78). In trinitrobenzene sulfonates provoke colitis rats, the colonic inflammation and necrotic lesions are also reduced by goat's milk oligosaccharides as compared with control rats (79). Though, it is not necessary that all findings using prebiotics shows a positive effect. Moreau et al. (80) reported oligofructose to be worthless in fixing dextran sodium sulfate evoked intestinal inflammation in rats, and Holma et al. (81) found same inefficaciousness of galacto-oligosaccharides in trinitrobenzene sulfonate induced-intestinal inflammation in rats.

\subsection{Inulin effect in human subjects}

Though there exists a scarcity of human studies utilizing prebiotics, a number of the emerging finding indicate that there is a prospect of this therapy modality. After colectomy for ulcerative colitis inulin shows a positive effect in the management of chronic pouchitis (82) Furrie et al. observe the usage of synbiotics (prebiotics plus probiotics) in 18 subjects with functional UC with the help of anew randomized, double-blinded controlled trial (83). This treatment involved grouping of prebiotics inulin and oligofructose. In the synbiotic nourished group, sigmoidoscopy inflammation scores were diminished as matched with the placebo group. The levels of intestinal TNF and IL-1a were also diminished. Moreover, the rectal culture revealed more epithelial regeneration and reduced inflammation in the synbiotictreated subjects. A tiny, open-labeled trial of 10 active CD subjects, 21 days of $15 \mathrm{~g}$ oligofructose and inulin oral administration shows a substantial lowering of the illness condition (84) (Table 6).

\subsection{Inulin beneficial effects in other medical conditions}

Inulin also shows a positive impact in the number of gastrointestinal complication, like management of infectious colitis, toddler diarrhoea, improvement of lipid metabolism minimised the risk of chemically induced colon cancer, improved absorption of calcium, relief of constipation, and management of diet intolerance (85-92).

\section{Conclusion}

Inulin is a promising nutraceutical in numerous medical conditions, including IBD. It is convenient to intake, economical, and has no major toxic impacts and may develop into an interesting adjunct to standard salutary in IBD. The dietetic use of inulin proposes a potential tactic to maintain health and wellbeing and to manage the progression of disorders. In human IBD, an inflated immune influence against commensal bacteria has been validated. Bacteria locally affect cytokine signalling, mucosal intrinsic responses and mucosal inflammation can also be down-regulated by certain bacteria. Saccharolysis by inulin in the large intestine support the growth of bifidobacteria and lactobacilli. Due to these impacts, there is a reduction in mucosal inflammation of IBD as illustrated in experimental models. Bacteria producing lactic acid can prevent endogenous microorganism from reproducing and obstruct adhesion and incursion of microorganism from outside the body. In this way, the prebiotic impact of inulin shows a positive effect on the barrier function of the bowel. In this manner, the prebiotic approach is a beneficial adjunct for susceptible subjects such as patients with severe disease and subject with persistent gastrointestinal disorders, such as colonic cancer and gut inflammation. In preliminary clinical trials, promising results have been achieved, but more studies 
are required to ensure the therapeutic use of inulin for the effective management of IBD.

\section{Acknowledgements}

The authors are please to acknowledge the financial support received from University Grant Commission (UGC) under the Scheme of "Maulana Azad National Fellowship" (MANF) and are highly obliged for their help and support in carrying out this work.

\section{References}

1. Steed H, Macfarlane GT, Macfarlane S. Prebiotics, synbiotics and inflammatory bowel disease. Mol Nutr Food Res. 2008; 5:898-905.

2. Gentschew L, Ferguson LR. Role of nutrition and microbiota in susceptibility to inflammatory bowel diseases. Mol Nutr Food Res. 2012; 56:524-535.

3. Chassaing B, Rolhion N, deValléeA, Salim SY, Prorok Hamon M, Neut C, Campbell BJ, Söderholm JD, Hugot JP, Colombel JF, Darfeuille-Michaud A. Crohn diseaseassociated adherent-invasive $E$. coli bacteria target mouse and human Peyer's patches via long polar fimbriae. J Clin Invest. 2011; 121:966-975.

4. Leenen $\mathrm{CH}$, Dieleman LA. Inulin and oligofructose in chronic inflammatory bowel disease. J Nutr. 2007; 37:2572S-2575S.

5. Sartor RB. Targeting enteric bacteria in the treatment of inflammatory bowel diseases: Why, how, and when. Curr Opin Gastroenterol. 2003; 19:358-365.

6. Sartor RB. Microbial influences in inflammatory bowel diseases. Gastroenterol. 2008; 134:577-594.

7. Tannock GW. The bowel microbiota and inflammatory bowel diseases. Int J Inflam. 2010; 2010:954051.

8. Bengmark S. Pre-, pro- and synbiotics. Curr Opin Clin Nutr Metab Car. 2001; 4:571-579.

9. Govers MJ, Gannon NJ, Dunshea FR, Gibson PR, Muir JG. Wheat bran affects the site of fermentation of resistant starch and luminal indexes related to colon cancer risk: A study in pigs. Gut. 1999; 45:840-847.

10. Nerstedt A, Nilsson EC, Ohlson K, Hakansson J, Thomas SL, Lowenadler B, Svensson UK, Mahlapuu M. Administration of Lactobacillus evokes coordinated changes in the intestinal expression profile of genes regulating energy homeostasis and immune phenotype in mice. Br J Nutr. 2007; 97:1117-1127.

11. Rioux KP, Fedorak RN. Probiotics in the treatment of inflammatory bowel disease. J Clin Gastroenterol. 2006; 40:260-263.

12. Barbosa TM, Serra CR, La Ragione RM, Woodward MJ, Henriques AO. Screening for bacillus isolates in the broiler gastrointestinal tract. Appl Environ Microbiol. 2005; 71:968-978.

13. Makharia GK, Ramakrishna BS, Abraham P, et al. Survey of inflammatory bowel diseases in India. Indian J Gastroenterol. 2012; 31:299-306.

14. Rahimi R, Nikfar S, RezaieA, Abdollahi M. A metaanalysis of antibiotic therapy for active ulcerative colitis. Dig Dis Sci. 2007; 52:2920-2925.

15. Russell RI. Review article: Dietary and nutritional management of Crohn's disease. Aliment Pharmacol Ther. 1991; 5:211-226.
16. Smith PA. Nutritional therapy for active Crohn's disease. World J Gastroenterol. 2008; 14:4420-4423.

17. Basson A. Nutrition management in the adult patient with Crohn's disease. South Afr J Clin Nutr. 2012; 25:164-172.

18. Hallert C, Kaldma M, Petersson BG. Ispaghula husk may relieve gastrointestinal symptom sinulcerative colitis in remission. Scand J Gastroenterol. 1991; 26:747-750.

19. Suwannaporn P, Thepwong K, Tester R, Al-Ghazzewi F, Piggott J, Shen N, Chen Z, Chen F, Yang J, Zhang $\mathrm{D}$, Tang $\mathrm{M}$. Tolerance and nutritional therapy of dietary fibre from konjac glucomannan hydrolysates for patients with inflammatory bowel disease (IBD). Bio Carbo Diet Fib. 2013; 2:93-98.

20. Sellon RK, Tonkonogy S, Schultz M, Dieleman LA, Grenther W, Balish ED, Rennick DM, Sartor RB. Resident enteric bacteria are necessary for the development of spontaneous colitis and immune system activation in interleukin-10-deficient mice. Infect Immun. 1998; 66:5224-5231.

21. Geier MS, Butler RN, Howarth GS. Inflammatory bowel disease: Current insights into pathogenesis and new therapeutic options; probiotics, prebiotics, and synbiotics. Int J Food Microbiol. 2007; 115:1-11.

22. Swidsinski A, Ladhoff A, Pernthaler A, Swidsinski S, Loening-Baucke V, Ortner M, Weber J, Hoffmann U, Schreiber S, Dietel M, Lochs H. Mucosal flora in inflammatory bowel disease. Gastroenterology. 2002; 122:44-54.

23. Thompson-Chagoyan OC, Maldonado J, Gil A. Aetiology of inflammatory bowel disease (IBD): The role of intestinal microbiota and gut-associated lymphoid tissue immune response. Clin Nutr. 2005; 24:339-352.

24. Sokol H, Seksik P, Rigottier-Gois L, Lay C, Lepage P, Podglajen I, Marteau P, Doré J. Specificities of the fecal microbiota in inflammatory bowel disease. Inflamm Bowl Dis. 2006; 12:106-111.

25. Kleessen B, Kroesen AJ, Buhr HJ, Blaut M. Mucosal and invading bacteria in patients with inflammatory bowel disease compared with controls. Scand J gastroenterol. 2002; 37:1034-1041.

26. Shanahan F. Host-flora interactions in inflammatory bowel disease. Inflamm Bowl Dis. 2004; 10:S16-S24.

27. Looijer-Van Langen MA, Dieleman LA. Prebiotics in chronic intestinal inflammation. Inflamm Bowl Dis. 2009; 15:454-462.

28. Goudberg A. The utilization of inulin in the metabolism for nutritional cures. Z Exp Path Ther. 1913; 13:310-325.

29. Phelps CF. The physical properties of inulin solutions. Biochem J. 1965; 95:41.

30. Crowe JH, Hoekstra FA, Crowe LM. Anhydrobiosis. Annu Rev of Physiol. 1992; 54:579-599.

31. Hinrichs WLJ, Prinsen MG, Frijlink HW. Inulin glasses for the stabilization of therapeutic proteins. Int J Pharma. 2001; 215:163-174.

32. Srinarong P, Faber JH, Visser MR, Hinrichs WLJ, Frijlink HW. The strongly enhanced dissolution rate of fenofibrate solid dispersion tablets by incorporation of superdisintegrants. Eur J Pharm Biopharm. 2009; 73:154161.

33. Van den Mooter G, Vervoort L, Kinget R. Characterization of methacrylated inulin hydrogels 845 designed for colon targeting: in vitro release of BSA. Pharm Res. 2003; 20:303-307.

34. Audouy SAL, Van der Schaaf G, Hinrichs WLJ, Frijlink 
HW, Wilschut J, Huckriede A. Development of a dried influenza whole inactivated virus vaccine for pulmonary immunization. Vaccine. 2011; 29:4345-4352.

35. Kumar S, Tummala H. Development of soluble inulin microparticles as a potent and safe vaccine adjuvant and delivery system. Mol Pharm. 2013; 10:1845-1853.

36. DenHond E, Geypens B, Ghoos Y. Effect of highperformance chicory inulin on constipation. Nutr Res. 2000; 20:731-736.

37. Marteau P, Jacobs H, Cazaubiel M, Signoret C, Prevel, JM, Housez B. Effects of chicory inulin in constipated elderly people: A double-blind controlled trial. Int J Food Sci Nutr. 2011; 62:164-170.

38. Leenen $\mathrm{CH}$, Dieleman LA. Inulin and oligofructose in chronic inflammatory bowel disease. J Nutr. 2007; 137:2572S-2575S.

39. Franck A. Technological functionality of inulin and oligofructose. Br J Nutr. 2002; 679 87:S287-S291.

40. Menne E, Guggenbuhl N, Roberfroid M. Fn-type chicory inulin hydrolysate has a prebiotic effect in humans. J Nutr. 2000; 130:1197-1199.

41. Kip P, Meyer D, Jellema RH. Inulins improve sensoric and textural properties of low-fat yoghurts. Int Dai J. 2006; 16:1098-1103.

42. Farzanmehr H, Abbasi S. Effects of inulin and bulking agents on some physicochemical, textural and sensory properties of milk chocolate. J Texture Stud. 2009; 40:536-553.

43. Cherbut $\mathrm{C}$. Inulin and oligofructose in the dietary fiber concept. Br J Nutr. 2002; 87:S159-S162.

44. Roberfroid MB. Functional foods: Concepts and application to inulin and oligofructose. Br J Nutr. 2002; 87:S139-S143.

45. Den Hond E, Geypens B, Ghoos Y. Effect of highperformance chicory inulin on constipation. Nutr Res. 2000; 20:731-736.

46. Oliveira RP, Perego P, De Oliveira MN, Converti A. Effect of inulin as a prebiotic to improve growth and counts of a probiotic cocktail in fermented skim milk. LWT-Food Sci Technol. 2011; 44:520-523.

47. Schultz M, Munro K, Tannock GW, Melchner I, Göttl C, Schwietz H, Schölmerich J, Rath HC. Effects of feeding a probiotic preparation (SIM) containing inulin on the severity of colitis and on the composition of the intestinal microflora in HLA-B27 transgenic rats. Clin Diagn Lab Immunol. 2004; 11:581-587.

48. Benyacoub J, Rochat F, Saudan KY, Rochat I, Antille N, Cherbut C, von der Weid T, Schiffrin EJ, Blum S. Feeding a diet containing a fructooligosaccharide mix can enhance Salmonella vaccine efficacy in mice. J Nutr. 2008; 138:123-129.

49. Ripoll C, Flourié B, Megnien S, Hermand O, Janssens M. Gastrointestinal tolerance to an inulin-rich soluble roasted chicory extract after consumption in healthy subjects. Nutrition. 2010; 26:799-803.

50. Gibson GR, Probert HM, Van Loo J, Rastall RA, Roberfroid MB. Dietary modulation of the human colonic microbiota: Updating the concept of prebiotics. Nutr Res Rev. 2004; 17:259-275.

51. Tuohy KM, Probert HM, Smejkal CW, Gibson GR. Using probiotics and prebiotics to improve gut health. Drug Discov Today. 2003; 8:692-700.

52. Hui YH, Evranuz EÖ. Handbook of vegetable preservation and processing (eds.). CRC Press, 2015.

53. Sartor RB. Therapeutic manipulation of the enteric microflora in inflammatory bowel diseases: Antibiotics, probiotics, and prebiotics. Gastroenterology. 2004; 126:1620-1633.

54. D'Haens GR, Geboes K, Peeters M, Baert F, Penninckx F, Rutgeerts P. Early lesions of recurrent Crohn's disease caused by infusion of intestinal contents in excluded ileum. Gastroenterology. 1998; 114:262-267.

55. Sartor RB. Enteric bacteria in chronic intestinal inflammation: Role in pathogenesis and therapeutic targets. Gastroenterology. 2003; 125.

56. Hammer RE, Maika SD, Richardson JA, Tang J, Taurog JD. Spontaneous inflammatory disease in transgenic rats expressing HLA-B27 and human b2m: An animal model of HLA-B27-associated human disorders. Cell. 1990; 63:1099-1112.

57. Taurog JD, Richardson JA, Croft JT, Simmons WA, Zhou M, Fernandez-Sueiro JL, Balish E, Hammer RE. The germfree state prevents the development of gut and joint inflammatory disease in HLA-B27 transgenic rats. J Exp Med. 1994; 180:2359-2364.

58. Sellon RK, Tonkonogy S, Schultz M, Dieleman LA, Grenther W, Balish E, Rennick DM, Sartor RB. Resident enteric bacteria are necessary for the development of spontaneous colitis and immune system activation in interleukin-10-deficient mice. Infect Immun. 1998; 66:5224-5231.

59. Rath H, Ikeda J, Wilson K, Sartor R. Varying cecal bacterial loads influence colitis and gastritis in HLA-B27 transgenic rats. Gastroenterology. 1999; 116:310-319.

60. Neut C, Bulois P, Desreumaux P, Membre JM, Lederman E, Gambiez L, Cortot A, Quandalle P, van Kruiningen $\mathrm{H}$, Colombel JF. Changes in the bacterial flora of the neoterminal ileum after ileocolonic resection for Crohn's disease. Am J Gastroenterol. 2002; 97:939-946.

61. Rath H, Wilson K, Sartor R. Differential induction of colitis and gastritis in HLA-B27 transgenic rats selectively colonized with Bacteroides vulgatus or Escherichia coli. Infect Immun. 1999; 67:2969-2974.

62. Griffin IJ, Davila PM, Abrams SA. Non-digestible oligosaccharides and calcium absorption in girls with adequate calcium intakes. Br J Nutr. 2002; 87:S187-S191.

63. Delzenne NM, Daubioul C, Neyrinck A, Lasa M, Taper HS. Inulin and oligofructose modulate lipid metabolism in animals: A review of biochemical events and future prospects. Br J Nutr. 2002; 87:S255-S259.

64. Nyman M. Fermentation and bulking capacity of indigestible carbohydrates: The case of inulin and oligofructose. Br J Nutr. 2002; 87:S163-S168.

65. Cummings JH, Christie S, Cole TJ. A study of fructo oligosaccharides in the prevention of travellers' diarrhoea. Aliment Pharmacol Ther. 2001; 15:11391145.

66. Saavedra JM, Tschernia A. Human studies with probiotics and prebiotics: Clinical implications. Br J Nutr. 2002; 87:S241-S246.

67. Olah A, Belagyi T, Issekutz A, Gamal ME, Bengmark S. Randomized clinical trial of specific lactobacillus and fiber supplement to early enteral nutrition in patients with acute pancreatitis. Br J Surg. 2002; 89:1103-1107.

68. Rayes N, Seehofer D, Hansen S, Boucsein K, Muller AR, Serke S, Bengmark S, Neuhaus P. Early enteral supply of lactobacillus and fiber versus selective bowel decontamination: A controlled trial in liver transplant recipients. Transplant. 2002; 74:123-127. 
69. Videla S, Vilaseca J, Antolı'n M, Garc1'a-Lafuente A, Guarner F, Crespo E, Casalots J, Salas A, Malagelada JR. Dietary inulin improves distal colitis induced by dextran sodium sulfate in the rat. Am J Gastroenterol. 2001; 96:1486-1493.

70. Cherbut C, Michel C, Lecannu G. The prebiotic characteristics of fructooligosaccharides are necessary for reduction of TNBS-induced colitis in rats. J Nutr. 2003; 133:21-27.

71. Femia AP, Luceri C, Dolara P, Giannini A, Biggeri A, Salvadori M, Clune Y, Collins KJ, Paglierani M, Caderni G. Antitumorigenic activity of the prebiotic inulin enriched with oligofructose in combination with the probiotics Lactobacillus rhamnosus and Bifidobacterium lactis on azoxymethane-induced colon carcinogenesis in rats. Carcinogenesis. 2002; 23:1953-1960.

72. Madsen KL, Doyle JS, Jewell LD, Tavernini MM, Fedorak RN. Lactobacillus species prevents colitis in interleukin 10 gene-deficient mice. Gastroenterology. 1999; 116:1107-1114.

73. McCarthy J, O'mahony L, O'callaghan L, Sheil B, Vaughan EE, Fitzsimons N, Fitzgibbon J, O'sullivan GC, Kiely B, Collins JK, Shanahan F. Double-blind, placebocontrolled trial of two probiotic strains in interleukin 10 knockout mice and mechanistic link with cytokine balance. Gut. 2003; 52:975-980.

74. Steidler L, Hans W, Schotte L, Neirynck S, Obermeier F, Falk W, Fiers W, Remaut E. Treatment of murine colitis by Lactococcus lactis secreting interleukin-10. Science. 2000; 289:1352-1355.

75. Kennedy RJ, Hoper M, Deodhar K, Kirk SJ, Gardiner KR. Probiotic therapy fails to improve gut permeability in a hapten model of colitis. Scand J Gastroenterol. 2000; 35:1266-1271.

76. Videla S, Vilaseca J, Antolı'n M, Garc1'a-Lafuente A, Guarner F, Crespo E, Casalots J, Salas A, Malagelada JR. Dietary inulin improves distal colitis induced by dextran sodium sulfate in the rat. Am J Gastroenterol. 2001; 96:1486-1493.

77. Hoentjen F, Welling G, Harmsen H, Zhang X, Snart J, Tannock GW, Lien K, Churchill TA, Lupicki M, Dieleman LA. Reduction of colitis in HLAB27 transgenic rats is associated with microflora changes and immunomodulation. Inflamm Bowel Dis. 2005; 11:977985.

78. Schultz M, Munro K, Tannock GW, Melchner I, Gottl C, Schwietz H, Schölmerich J, Rath HC. Effects of feeding a probiotic preparation (SIM) containing inulin on the severity of colitis and on the composition of the intestinal microflora in HLA-B27 transgenic rats. Clin Diagn Lab Immun. 2004; 11:581-587.

79. Lara-Villoslada F, Debras E, Nieto A, Concha A, Galvez J, Lopez- Huertas E, Boza J, Obled C, Xaus J. Oligosaccharides isolated from goat milk reduce intestinal inflammation in a rat model of dextran sodium sulfateinduced colitis. Clin Nutr. 2006; 25:477-488.

80. Daddaoua A, Puerta V, Requena P, Martinez-Ferez A, Guadix E, de Medina FS, Zarzuelo A, Suarez MD, Boza JJ, Martinez-Augustin O. Goat milk oligosaccharides are anti-inflammatory in rats with hapten-induced colitis. J
Nutr. 2006; 136:672-676

81. Moreau NM, Martin LJ, Toquet CS, Laboisse CL, Nguyen PG, Siliart BS, Dumon HJ, Champ MM. Restoration of the integrity of rat caecocolonic mucosa by resistant starch, but not by fructo-oligosaccharides, in dextran sulfate sodium-induced experimental colitis. Br J Nutr. 2003; 90:75-78.

82. Holma R, Juvonen P, Asmawi MZ, Vapaatalo H, Korpela R. Galactooligosaccharides stimulate the growth of bifidobacteria but fail to attenuate inflammation in experimental colitis in rats. Scand J Gastroenterol. 2002; 37:1042-1047.

83. Welters CF, Heineman E, Thunnissen FB, van den Bogaard AE, Soeters PB, Baeten CG. Effect of dietary inulin supplementation on inflammation of pouch mucosa in patients with an ileal pouch-anal anastomosis. Dis Colon Rectum. 2002; 45:621-627.

84. Furrie E, Macfarlane S, Kennedy A, Cummings JH, Walsh SV, O'Neil DA, Macfarlane GT. Synbiotic therapy (Bifidobacterium longum/Synergy 1) initiates resolution of inflammation in patients with active ulcerative colitis: A randomized controlled pilot trial. Gut. 2005; 54:242249.

85. Lindsay JO, Whelan K, Stagg AJ, Gobin P, Al-Hassi HO, Rayment N, Kamm MA, Knight SC, Forbes A. Clinical, microbiological, and immunological effects of fructooligosaccharide in patients with Crohn's disease. Gut. 2006; 55:348-355.

86. Swennen K, Courtin CM, Delcour JA. Non-digestible oligosaccharides with prebiotic properties. Crit Rev Food Sci Nutr. 2006; 46:459-471.

87. Ten Bruggencate SJ, Bovee-Oudenhoven IM, LettinkWissink ML, Katan MB, Van Der Meer R. Dietary fructooligosaccharides and inulin decrease resistance of rats to salmonella: Protective role of calcium. Gut. 2004; 53:530535 .

88. Bovee-Oudenhoven IM, Ten Bruggencate SJ, LettinkWissink ML, Van der Meer R. Dietary fructooligosaccharides and lactulose inhibit intestinal colonization but stimulate translocation of salmonella in rats. Gut. 2003; 52:1572-1578.

89. Osman N, Adawi D, Molin G, Ahrne S, Berggren A, Jeppsson B. Bifidobacterium infantis strains with and without a combination of oligofructose and inulin (OFI) attenuate inflammation in DSS-induced colitis in rats. BMC Gastroenterol. 2006; 6:31.

90. Mangell P, LennernÄs P, Wang M, Olsson C, AhrnÉ S, Molin G, Thorlacius H, Jeppsson B. Adhesive capability of Lactobacillus plantarum $299 \mathrm{v}$ is important for preventing bacterial translocation in endotoxemic rats. APMIS. 2006; 114:611-618.

91. Anderson AD, McNaught CE, Jain PK, MacFie J. Randomised clinical trial of synbiotic therapy in elective surgical patients. Gut. 2004; 53:241-245.

92. Macfarlane S, Macfarlane GT, Cummings JH. Review article: Prebiotics in the gastrointestinal tract. Aliment Pharmacol Ther. 2006; 24:701-714

(Received January 2, 2019; Revised February 20, 2019; Accepted February 25, 2019) 